\title{
FIRST RECORD OF THE GENUS XEROPICTA MONTEROSATO, 1892 (GASTROPODA: EUPULMONATA: GEOMITRIDAE) IN SERBIA
}

\author{
VUKAŠIN GOJŠINA ${ }^{1 *}$, BARNA PÁLl-GERGELY², MIHAILO VuJIĆ ${ }^{3}$, IVAILO DEDOV $^{4}$ \\ ${ }^{1}$ Department of Morphology, Systematics and Phylogeny of Animals, University of Belgrade, \\ Faculty of Biology, Studentski trg 16, 11000, Belgrade, Serbia (e-mail: mr.gojsinavukasin@gmail.com); \\ (1) https://orcid.org/0000-0002-0413-9304 \\ 2 Plant Protection Institute, Centre for Agricultural Research, Hungary; \\ (1) https://orcid.org/0000-0002-6167-7221 \\ ${ }^{3}$ HabiProt, Serbia; (D) https://orcid.org/0000-0003-1633-7831 \\ ${ }^{4}$ Institute of Biodiversity and Ecosystem Research, Bulgarian Academy of Sciences, Bulgaria; \\ (D) https://orcid.org/0000-0003-4445-359X \\ * corresponding author
}

\begin{abstract}
Xeropicta Monterosato is a pulmonate xerophilous snail genus of the family Geomitridae. It is distributed in the eastern Mediterranean and the Black Sea region and also in Asia Minor, Ukraine, the Caucasus, the Middle East and Iran. No species of this genus was known from Serbia until now. Here, we present the first record of Xeropicta from Serbia. Morphological, anatomical and ecological characteristics of the species as well as its variation are discussed. Because of the wide shell variation, the analysed specimens were identified based on anatomy, and correspond to X. krynickii. However, in their shell morphology, some specimens resemble $X$. derbentina. Therefore, here they are treated as $X$. cf. krynickii. Further studies should shed more light on their identity.
\end{abstract}

KEYWORDS: geomitrid snails; morphology; reproductive anatomy; distribution

\section{INTRODUCTION}

A large body of data on land snails of Serbia was collected by Petar S. Pavlović, most intensively in the period from 1905 to 1912 (PAVLOVIĆ 1912, TOMIĆ 1959). His material is now in the Natural History Museum in Belgrade. Later, the land snails and slugs of Serbia were studied by Božana Karaman at the end of the 20th and the beginning of the 21st century. She published numerous faunistic papers and summarised most of her data in the checklist of gastropods of Serbia (KARAMAN 2007). In that list, she reported a total of 184 species of land snails and slugs. As many species names have changed in the meantime, as well the species number in general, the list requires significant changes. Moreover, there are some species in that list that occur in adjacent countries but their presence in Serbia is doubtful. There is a possibility that some of the records are actually from Montenegro. This can be explained by the fact that Serbia and Montenegro were one country until 2006; the checklist was published in 2007 and these species were probably in- cluded accidentally. However, the list of species and the commentary on the general diversity of Serbian gastropods is beyond the scope of this paper.

Xeropicta Monterosato, 1892 is a pulmonate xerophilous snail genus of the family Geomitridae (MOlluscaBAse 2021). It is distributed in the eastern Mediterranean and the Black Sea region, as well as in Asia Minor, Ukraine, the Caucasus, the Middle East and Iran (DE MATTIA 2007). Four species of Xeropicta inhabit Europe, namely: X. akrotirica Gittenberger, 1991, X. derbentina (Krynicki, 1836), X. krynickii (Krynicki, 1833) and X. ledereri (L. Pfeiffer, 1856). Of these four species, two - X. akrotirica and $X$. ledereri - are known only from Cyprus, while the other two are more widely distributed (WELTERSCHULTES 2012). Xeropicta krynickii is distributed in the eastern part of the Mediterranean region and reaching the Caspian Sea, but is also present in its western parts, for example in Montenegro, which is also the westernmost known fragment of its distri- 


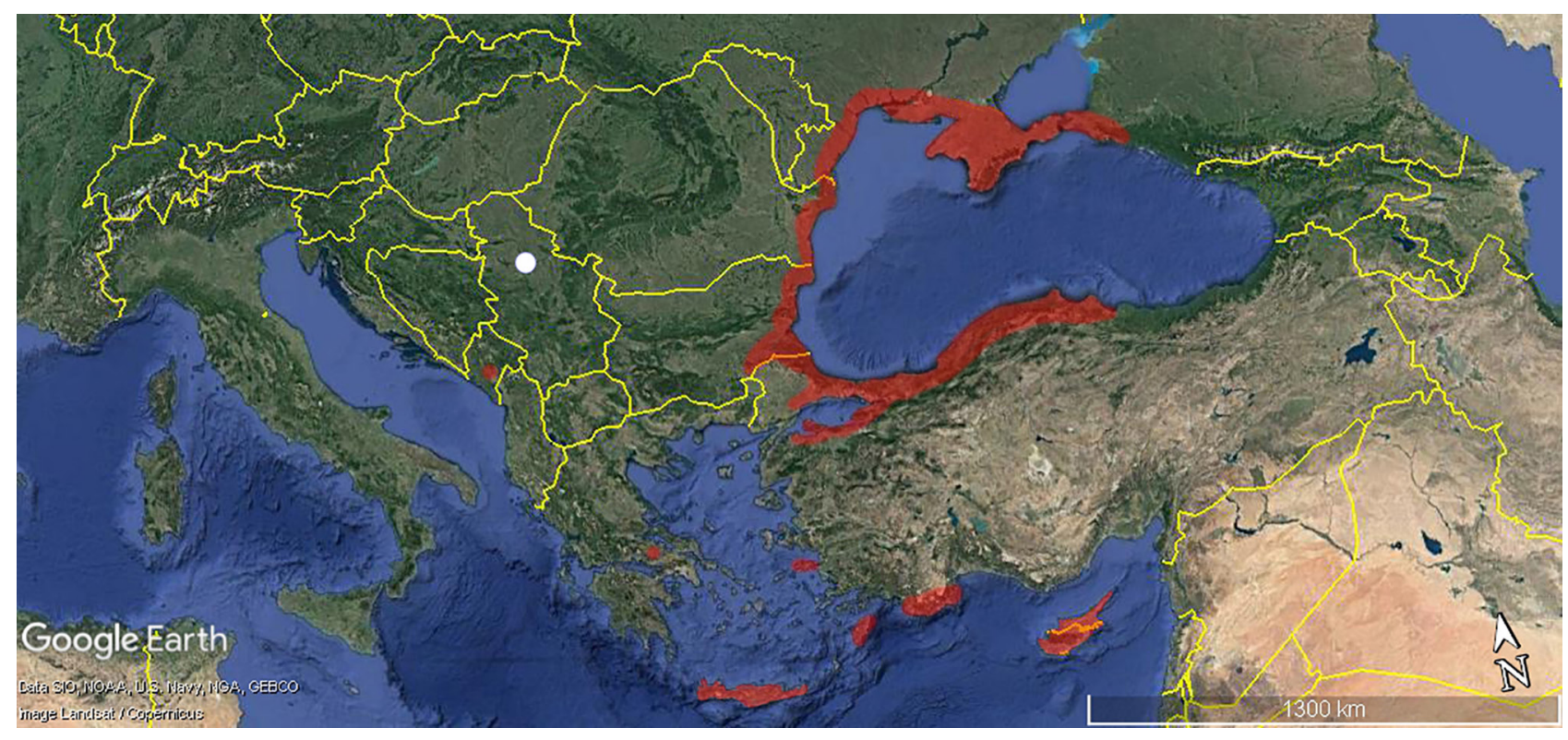

Fig. 1. Estimated range of X. krynickii (according to WeLTER-SCHUlTES 2012, DE MATTIA \& PEŠIĆ 2014 and GURALSVERLOVA \& GURAL 2017). White dot represents the new record from Serbia

bution (Fig. 1). Xeropicta derbentina is found around the Black Sea region, the Caucasus, Asia Minor as well as in Italy, France and northeast Africa (DE MATtia 2007, Welter-SChultes 2012, De MATTIA \& PEŠIĆ 2014, GURAL-SVERLOVA \& GURAL 2017). No species of the genus was recorded from Serbia until now. Here we present the first record of the genus Xeropicta in Serbia. Because of the wide conchological variation, we have examined both anatomical and conchological characters; we discuss their implications for the species identification. These snails are important because they spread easily (GURALSVERLOVA \& GURAL 2017), are intermediate hosts of many parasites (ANDERSON 2000, MEERBURG et al. 2009, KuChBOeV et al. 2012, GÉRARD et al. 2020), and agricultural pests (STOJNIĆ et al. 2013). Because of this, documenting their spread is of particular importance (DE MATtia \& PÁLL-GERgelY 2014).

\section{MATERIAL AND METHODS}

In Vrčin settlement, Grocka municipality in Belgrade (coordinates: 4440'35.50"N, 20³6'28.88"E; altitude: $149 \mathrm{~m}$ a.s.l.) (Fig. 1), around 40 specimens of X. krynickii were collected on 15.05.2021 in a house yard. All snails were collected by hand and preserved in $70 \%$ ethanol. Their shells and genitalia were photographed and basic shell characters were measured (shell and aperture height and width, umbilicus width) using stereomicroscope Nikon

\section{RESULTS}

Family Geomitridae C.R. Boettger, 1909

\section{Subfamily Helicellinae Ihering, 1909}

\section{Genus Xeropicta Monterosato, 1892}

\section{Xeropicta cf. krynickii (Krynicki, 1833)}

General description of the species. Shell consisting of 4-5.5 whorls. Colouration white with brown-
SMZ800N equipped with a Nikon DS-Fi2 camera. A Nikon DS-L3 control unit was used to set scale bars. Snails were identified conchologically and anatomically following SCHILEYKO (2006), DE MATTIA \& PEŠIĆ (2014) and GURAL-SVERLOVA \& GURAL (2017). The distribution map was made using Google Earth Pro application (7.3.4.8248 (64-bit)). The specimens are deposited at the Institute of Zoology, Faculty of Biology, Belgrade. ish bands and spots, or uniformly white. Shell surface finely striated. Body whorl slightly descending near the aperture. Umbilicus narrow and slightly eccentric, with 0.5 previous whorl visible through it (although some of our specimens anatomically resembling $X$. krynickii do not show the described appearance of umbilicus (Fig. 2)). Body pale yellowish, mantle creamy (Welter-SchUltes 2012, GURAL- 


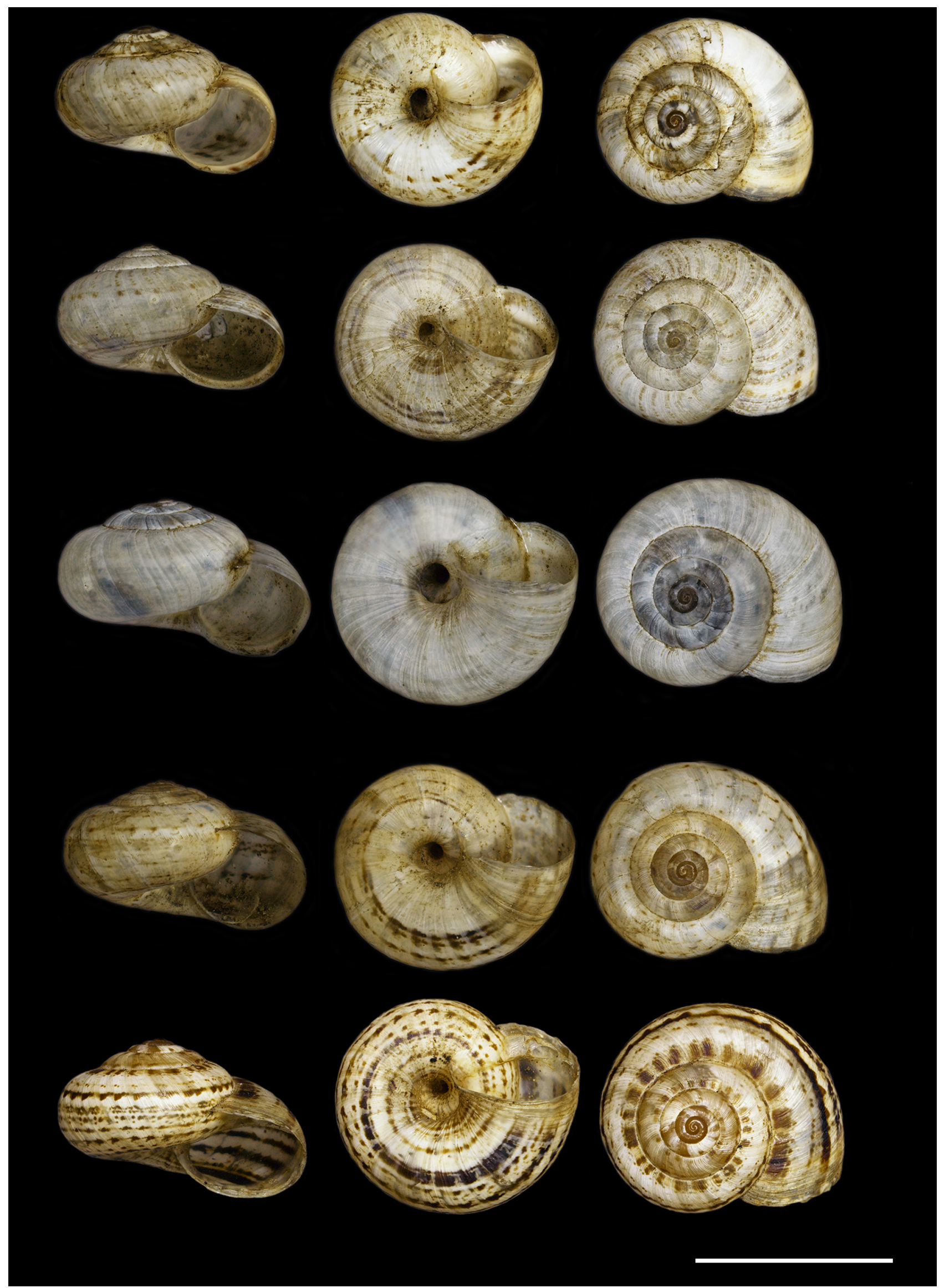

Fig. 2. Specimens of $X$. cf. krynickii from Belgrade (Serbia). Scale bar $10 \mathrm{~mm}$ 

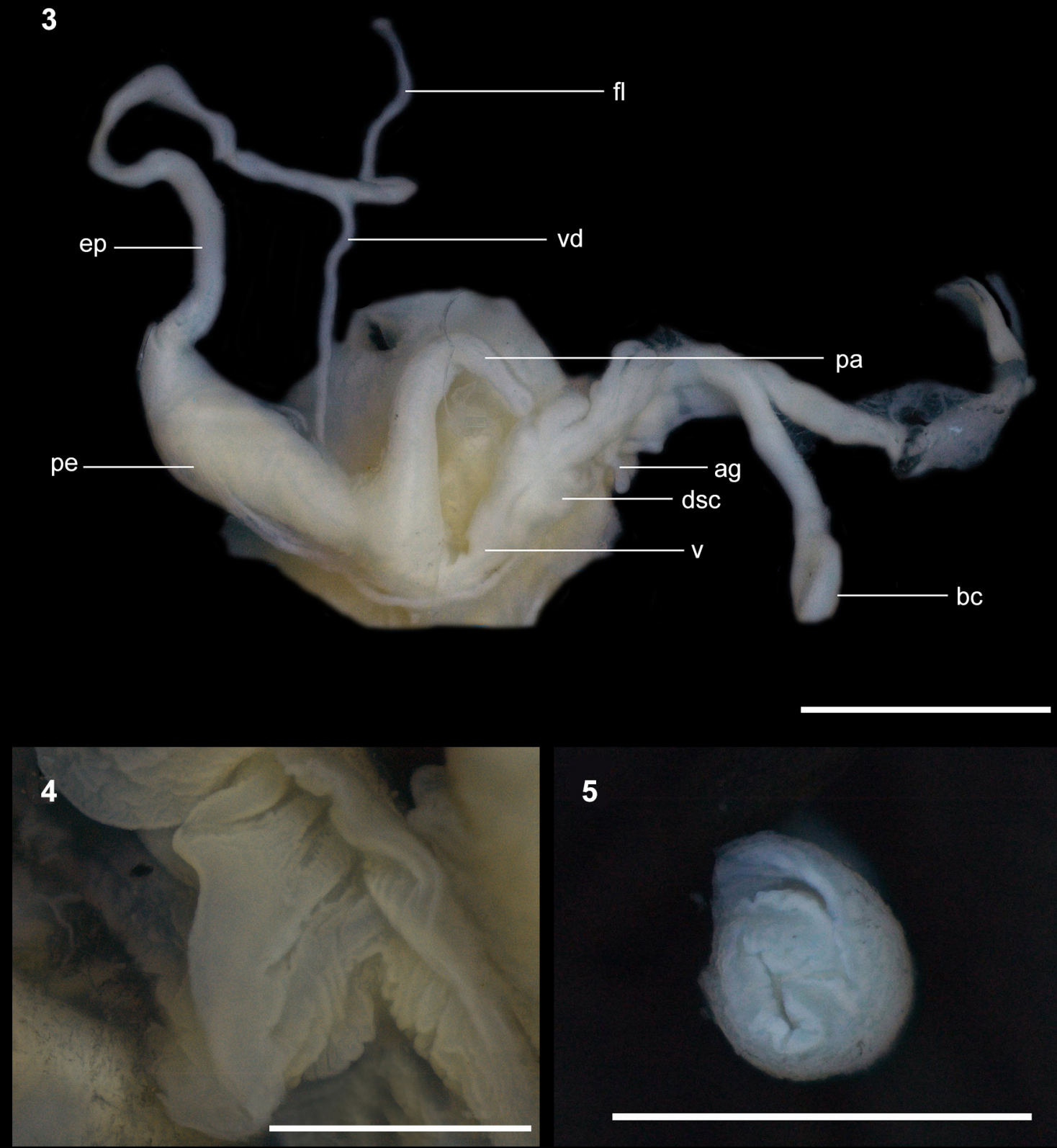

5

\section{6}

7

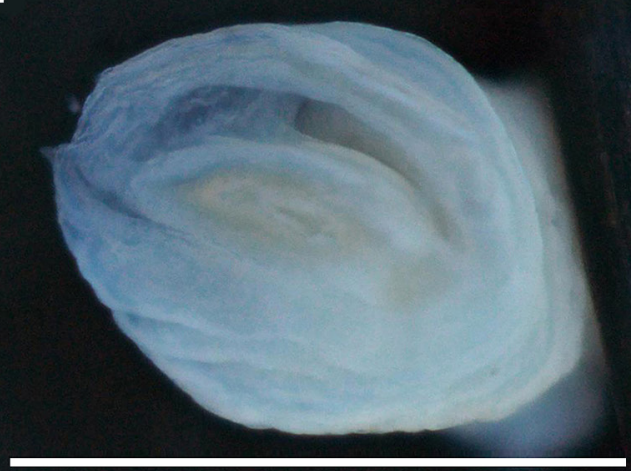

Figs 3-7. Genitalia of X. cf. krynickii. 3 - whole genitalia (excluding gonad); 4 - internal structure of a part of penial appendix; 5 - transverse section of penial appendix; 6 - penial papilla; 7 - transverse section of penial papilla. ag - accessory gland; bc - bursa copulatrix; dsc - dart sac complex; ep - epiphallus; fl - flagellum; pa - penial appendix; pe - penis; $\mathrm{v}$ - vagina; vd - vas deferens. Scale bar $1 \mathrm{~mm}$ 
SVERLOVA \& GURAL 2017). Penis with long flagellum, 2 or 3 times shorter than epiphallus (Fig. 3). Inside penis, a strongly developed penial papilla with an outer sheath (Figs 4-7). Vagina with 10-14 digitiform accessory glands and dart-sac complex consisting of four stylophores entering vagina independently (Fig. 3). Darts present in proximal stylophores and absent in distal ones. Penial appendage strongly developed. A crest-like structure can be found inside penial appendage gradually increasing in height until reaching the atrial aperture (DE MATTIA \& PEŠIĆ 2014) (Figs 3-4).

Comparison with similar species. The species can be easily confused with $X$. derbentina and dissection is

\section{DISCUSSION}

The analysed specimens from the population in Belgrade showed relatively small variation in shell dimensions (only $3 \mathrm{~mm}$ difference between the largest and the smallest specimen). The umbilicus was $1 / 6$ of shell width in most cases, sometimes $1 / 5$. However, significant variation was observed regarding shell colouration (Fig. 2). Some specimens were uniformly white with a light band, sometimes faintly visible, in the middle of the periphery. Other specimens were more intensively coloured, with variable number of more or less pronounced brownish bands, sometimes broken into numerous brownish freckles, giving the shell a much darker appearance. In some specimens, the shell was almost entirely white with faint brownish bands only on the body whorl. No significant anatomical variation was observed. In all the specimens dissected $(n=5)$, the flagellum was approximately 2.5 times shorter than the epiphallus. These snails are known to vary greatly in their shell needed to separate them clearly. Xeropicta derbentina also has a dart-sac complex consisting of four stylophores but it has a short flagellum, much shorter than the epiphallus (DE MATTIA \& PEŠIĆ 2014). The other two geomitrids which occur in Serbia and can be confused with X. krynickii are Xerolenta obvia (Menke, 1828) and Cernuella virgata (Da Costa, 1778). However, both $X$. obvia and C. virgata have two dart sacs and not four like X. krynickii (SCHILEYKO 2006). Conchologically, X. obvia is usually flatter with wider umbilicus and C. virgata is usually larger and more globular (WELTER-SCHULTES 2012).

appearance, and proper identification often requires dissection and observation of anatomical traits, as stated by DE MATTIA \& PEŠIĆ (2014) who also found a population of X. krynickii resembling X. obvia in its external appearance. Our population included several specimens externally resembling $X$. derbentina, but all of those matched X. krynickii anatomically. Because of these "shared" characters, none of our specimens could be identified to the species level with absolute certainty. Finding and analysing more populations could resolve the confusion and even confirm the presence of both species in Serbia.

Xeropicta is adapted to many xerothermic habitats and is easily dispersed by humans (GURAL-SVERLOVA \& GURAL 2017). Xeropicta krynickii, as well as X. derbentina, expanded its distribution range significantly due to human activities. One of the examples is road and railway transport (GURAL-SVERLOVA \& GLEBA 2015). It is almost certain that the presence

Table 1. Measurements of specimens of X. cf. krynickii from Belgrade (Serbia)

\begin{tabular}{lccccc}
\hline & $\begin{array}{c}\text { Shell height } \\
(\mathrm{mm})\end{array}$ & $\begin{array}{c}\text { Shell width } \\
(\mathrm{mm})\end{array}$ & $\begin{array}{c}\text { Aperture height } \\
(\mathrm{mm})\end{array}$ & $\begin{array}{c}\text { Aperture width } \\
(\mathrm{mm})\end{array}$ & $\begin{array}{c}\text { Umbilicus width } \\
(\mathrm{mm})\end{array}$ \\
\hline Specimen 1 & 7.8 & 11.0 & 4.8 & 5.2 & 1.9 \\
Specimen 2 & 8.7 & 13.5 & 5.1 & 6.2 & 2.3 \\
Specimen 3 & 8.7 & 13.4 & 5.0 & 6.5 & 2.3 \\
Specimen 4 & 7.7 & 12.6 & 5.2 & 6.2 & 2.2 \\
Specimen 5 & 8.2 & 14.0 & 5.4 & 6.9 & 2.5 \\
Specimen 6 & 7.8 & 11.3 & 4.2 & 5.2 & 2.1 \\
Specimen 7 & 8.4 & 13.3 & 5.0 & 6.1 & 2.0 \\
Specimen 8 & 8.2 & 13.0 & 4.8 & 6.5 & 2.1 \\
Specimen 9 & 7.0 & 11.0 & 4.1 & 5.1 & 1.9 \\
Specimen 10 & 7.9 & 12.9 & 4.4 & 6.6 & 2.1 \\
Specimen 11 & 8.0 & 12.7 & 4.6 & 5.9 & 2.2 \\
Specimen 12 & 7.0 & 11.4 & 4.3 & 5.9 & 1.9 \\
Specimen 13 & 7.6 & 11.6 & 4.0 & 5.6 & 2.8 \\
Specimen 14 & 8.3 & 11.5 & 4.3 & 6.0 & 2.1 \\
Mean & 7.9 & 12.4 & 4.6 & & 2.1 \\
\hline
\end{tabular}


of Xeropicta in Belgrade is caused by human transport, since the single population which we studied is relatively close to the place of storage of various goods brought from different countries of Europe. The snails were found only in this area and not elsewhere. GURAL-SVERLOVA \& GURAL (2017) have shown that $X$. krynickii is more related to coastal habitats while deeper inland, $X$. derbentina is more common, though with some exceptions, as in the case of some larger rivers of the Black Sea basin. Our record of X. krynickii from Belgrade certainly belongs to more inland type of records.

It is known that xerophilous snails can be agricultural pests (STOJNIĆ et al. 2013) and intermediate hosts of important parasites of different vertebrates (ANDERSON 2000, MEerburG et al. 2009, KuCHBOEV et al. 2012, GÉRARD et al. 2020). According to ANDERSON (2000), snails of the genera Cernuella, Cochlicella, Helicella, Xerolenta and Xeropicta are intermediate hosts of lung nematode parasites of several artiodactyls. A study from Uzbekistan (KUCHBOEV et al. 2012) showed that $X$. candaharica (L. Pfeiffer, 1846) was the species of land snail most commonly infected by the nematodes of the family Protostrongylidae, lung parasites of Bovidae mostly. These snails also serve as intermediate hosts of some trematodes, for example the genus Brachylaima (GÉRARD et al. 2020). Apart from rodents, these trematodes can also infect humans and cause brachylaimiasis manifested by abdominal pain and diarrhea with mortality between $5 \%$ and $10 \%$ when untreated (MEERBURG et al.

\section{REFERENCES}

ANDERSON R. C. 2000. Nematode parasites of vertebrates. Their development and transmission. 2nd Edition. CABI Publishing, Wallingford, Oxon (UK). https://doi.org/10.1079/9780851994215.0001

DE MATTIA W. 2007. Xeropicta derbentina (Krynicky, 1836) (Gastropoda, Hygromiidae) in Italy and along the Croatian coast, with notes on its systematics and nomenclature. Basteria 71: 1-12.

De Mattia W., PÁll-Gergely B. 2014. Records of Xerocrassa muehlfeldtiana (Rossmässler 1837) refer to $X$. rhabdota (Sturany 1901): Redescription of the species and detailed anatomical description of other Balkan Xerocrassa species (Gastropoda: Pulmonata). Journal of Conchology 41: 1-12.

De MATtiA W., PeŠIĆ V. 2014. Xeropicta (Gastropoda, Hygromiidae) goes west: the first record of X. krynickii (Krynicki, 1833) for Montenegro, with a description of its shell and genital morphology, and an additional record of $X$. derbentina (Krynicki, 1836) for Italy. Ecologica Montenegrina 1: 193-200.

https://doi.org/10.37828/em.2014.1.27

Gérard C., Ansart A., DeCAnter N., Martin M. C., DAHIREL M. 2020. Brachylaima spp. (Trematoda) par-
2009). Xerophilous snails are mostly second intermediate hosts of these trematodes but, for example, $X$. krynickii is the first intermediate host of Brachylaima mesostoma (Rudolphi, 1803) though it can also be the second along with several other species (GÉRARD et al. 2020). As pests, a study from Serbia has shown that $C$. virgata caused enough damage to green onion in vegetable plots to make it unfit to be eaten or sold, and there are numerous other examples all over the world (STOJNIĆ et al. 2013). Xerolenta obvia is reported from Andorra as invasive species, and is known as an intermediate host of many parasites, as well as an agricultural pest (MARTÍNEZ-ORTÍ \& BORREDÀ 2022). In the USA, there are several reports of Theba pisana (O. F. Müller, 1774) (Helicidae) as an agricultural pest (VENDETTI et al. 2021).

The importance of these snails as intermediate hosts of various parasites and as agricultural pests further emphasises the importance of their correct identification and of documenting their spread or decline (De Mattia \& PÁll-Gergely 2014). It is important to note that this species has not caused any damage till now, but its spread, as well as possible methods of its control if necessary, will be further studied.

\section{ACKNOWLEDGEMENTS}

We would like to thank the reviewers for their useful comments which helped to improve this manuscript.

asitizing Cornu aspersum (Gastropoda) in France with potential risk of human consumption. Parasite 27: 15. https://doi.org/10.1051/Parasite/2020012

Gural-Sverlova N. V., Gleba V. M. 2015. New passing in the malacological collection of the State Natural History Museum of the National Academy of Sciences of Ukraine from Transcarpathian oblast. Naukovi Zapiski Gosudarstvennogo Prirodno Muzea 31: 39-44.

GurAl-Sverlova N. V., Gural R. I. 2017. Expansion of the ranges of land mollusks of the genus Xeropicta (Gastropoda, Hygromiidae) in Ukraine. Russian Journal of Biological Invasions 8: 212-217. https://doi.org/10.1134/S2075111717030043

KARAMAN B. 2007. Checklist of snails (Mollusca, Gastropoda) of Serbia. Glasnik Republičkog Zavoda Zaštite Prirode Podgorica 29-30: 131-148.

Kuchboev A. E., Karimova R. R., Ruziev B. H., AzImov D. A. 2012. Ecological aspects of nematodes of the family Protostrongylidae, parasites of Bovidae. Scientia Parasitologica 13: 17-25.

MARTínEZ-OrTí A., BORREDÀ V. 2022. About the finding of the invasive geomitrid Xerolenta obvia (Menke, 1828) 
(Mollusca, Stylommatophora) in Andorra. Zoolentia 2/2022: 1-6.

Meerburg B. G., Singleton G. R., Kijlstra A. 2009. Rodent-borne diseases and their risks for public health. Critical Reviews in Microbiology 35: 221-270. https://doi.org/10.1080/10408410902989837

MOllusCABASE 2021. Xeropicta krynickii (Krynicki, 1833). Available online at: http://www.molluscabase.org/ aphia.php? $\mathrm{p}=$ taxdetails\&id $=1002546 \quad$ (accessed 13 January 2022).

PAVlović P. S. 1912. Mekušci iz Srbije (Vol. 39). Srpska Kraljevska Akademija, Belgrade.

SCHILEYKO A. A. 2006. Treatise on recent terrestrial pulmonate molluscs. Part 14. Helicodontidae, Ciliellidae, Hygromiidae. Ruthenica, supplement 2: 1907-2047.

STOJNIĆ B., JOKIĆ G., ĐEDOVIĆ S., VUKČA M. 2013. Damage caused by White Snail Cernuella virgata (Da Costa) to green onion crop. Pesticides and Phytomedicine 28: 247-253.

https://doi.org/10.2298/PIF1304247S

TOMIĆ V. 1959. Zbirka recentnih puževa PS Pavlovića, u Prirodnjačkom Muzeju u Beogradu. SANU, Posebna izdanja 27: 1-74.

VendetTi J. E., SANDIG K., SAHAKYAN A., GRANAdOS A. 2021. Multiple introductions of the pestiferous land snail Theba pisana (Müller, 1774) (Gastropoda: Helicidae) in Southern California. Insects 12: 662. https://doi.org/10.3390/insects12080662

WELTER-SCHULTES F. W. 2012. European non-marine molluscs, a guide for species identification. Bestimmungsbuch für europäische Land-und Süsswassermollusken. Planet Poster Editions, Göttingen.

Received: January 14th, 2022

Revised: February 22nd, 2022

Accepted: February 24th, 2022

Published on-line: March 5th, 2022 